\title{
Faktor-Faktor Risiko dan Komplikasi pada Preeklamsi dengan Sindroma HELLP
}

\author{
Rikki Fitriyadi, Anita Deborah Anwar, Hanom Husni Syam \\ Departemen Obstetri dan Ginekologi Fakultas Kedokteran Universitas Padjadjaran \\ Rumah Sakit Dr. Hasan Sadikin Bandung \\ Korespondensi: Rikki Fitriandi, Email: rikki.fitriyadi90@gmail.com
}

\begin{abstract}
Abstrak
Tujuan: Penelitian ini bertujuan untuk mengetahui faktor risiko terjadinya preeklamsi dengan sindroma HELLP, serta faktor yang memengaruhi keadaan ibu dan janin pada pasien dengan preeklamsi dengan atau tanpa sindroma HELLP.

Metode: Penelitian retrospektif ini mengambil subjek pada periode 1 Januari 2011-31 Desember 2016. Subjek dimasukkan ke dalam dua kelompok, yaitu kelompok preeklamsi tanpa sindroma HELLP dan kelompok preeklamsi dengan sindroma HELLP. Data berupa faktor risiko serta faktor yang memengaruhi keadaan ibu dan janin dari anamnesis riwayat penyakit dahulu pasien.

Hasil: Penelitian ini mengikutsertakan 200 subjek yang dibagi menjadi dua kelompok. Ibu berusia lebih dari 35 tahun ditemukan pada 27\% subjek di kelompok sindroma HELLP, sedangkan hanya 5\% pada kelompok tanpa sindroma HELLP. Pada kelompok dengan sindroma HELLP ditemukan hematoma hepatik sebanyak 3\%, tetapi tidak ada pada kelompok tanpa sindroma HELLP. Komplikasi janin yang paling banyak terjadi pada kelompok dengan sindroma HELLP dan kelompok tanpa sindroma HELLP adalah kelahiran prematur, yaitu masing-masing $42 \%$ dan $39 \%$.

Kesimpulan: Sindroma HELLP sering terjadi pada subjek yang berusia diatas 35 tahun. Hematoma hepatik hanya ditemukan pada kelompok dengan sindroma HELLP. Kejadian komplikasi kelahiran prematur tinggi pada kedua kelompok.
\end{abstract}

Kata kunci: Preeklamsi, sindroma HELLP, faktor risiko, komplikasi ibu, komplikasi janin

\section{Risk Factors and Complications in Preeclampsia with HELLP Syndrome}

\begin{abstract}
Objective: This study is important to investigate the risk factors of preeclampsia with HELLP syndrome and the factors which influenced maternal and fetal condition in preeclampsia with or without HELLP syndrome patients. Method: This was a retrospective study during 1st of January 2011 till 31 st of December 2016 with preeclamptic patients as subjects. These subjects then were categorized into two groups, preeclampsia with HELLP syndrome group and preeclampsia without HELLP syndrome group. The data related to risk factors and factors which influenced maternal and fetal condition were taken from anamnesis of patients medical history.

Results: This study participated 200 subjects which were divided into two groups. Maternal age $>35$ years old was found in $27 \%$ of with HELLP syndrome group, while only $5 \%$ in without HELLP syndrome group. Hepatic hematoma was found in 3\% of HELLP syndrome group, but none in without HELLP syndrome group. Preterm birth in both groups was $42 \%$ and $39 \%$ respectively.

Conclusions: HELLP syndrome was more found in subjects whose age above 35. Hepatic hematoma was found only in HELLP syndrome group. The incidence of preterm birth was high in both groups.
\end{abstract}

Key words: Preeclampsia, HELLP syndrome, risk factors, maternal complication, fetal complication. 


\section{Pendahuluan}

Preeklamsi merupakan komplikasi kehamilan yang ditandai oleh hipertensi dan proteinuria yang sebelumnya tidak ada. Preeklamsi terjadi pada 1,6-3,6\% kehamilan di Asia. Di Indonesia, insidensi preeklamsi sekitar 3,4-8,5\% dari seluruh kehamilan. Insidensi preeklamsi di Departemen Obstetri dan Ginekologi Rumah Sakit Hasan Sadikin pada tahun 2007-2009 adalah 0,97-2,08\%, sedangkan preeklamsi berat adalah 1,332,94\%. Angka kejadian kasus preeklamsi dipengaruhi oleh paritas, etnis, ras dan genetik. Preeklamsi masih menjadi penyebab utama kematian ibu (32\%) di Indonesia. ${ }^{1,2}$

Preeklamsi dapat diperberat dengan 4 hal yaitu eklamsi, insufisiensi ginjal, disseminated intravascular coagulopathy (DIC) dan dapat berkembang menjadi sindroma HELLP. Sindroma HELLP adalah suatu sindroma yang terdiri dari hemolisis $(\mathrm{H})$, peningkatan enzim hati (EL) dan jumlah trombosit yang rendah (LP). Pritchard dkk pada tahun 1954 merupakan yang pertama kali menjelaskan bahwa sindroma HELLP merupakan varian dari preeklamsi, terutama preeklamsi berat. Sekitar 8-24\% kehamilan dengan preeklamsi berat mengalami sindroma HELLP. $^{1-3}$

Insidensi terjadinya hematoma hepatic maternal pada kasus sindroma HELLP adalah 1,6\%. Selain itu, $6 \%$ mengalami eklamsi, $10 \%$ mengalami abrupsio plasenta, $5 \%$ mengalami gagal ginjal akut, dan $10 \%$ mengalami edema paru. Komplikasi berat lainnya bagi ibu antara lain, stroke, koagulopati, acute respiratory distress syndrome (ARDS), dan sepsis. Penelitian juga melaporkan bahwa komplikasi yang dapat terjadi pada bayi meliputi berat badan lahir rendah, kematian janin intrauterus, pertumbuhan janin terhambat, kematian neonatus dan perawatan di unit intensif neonatus. ${ }^{3-5}$

Oleh karena itu, penting untuk mengetahui tentang faktor risiko terjadinya preeklamsi dengan sindroma HELLP beserta faktor-faktor yang memengaruhi keadaan ibu dan janin pada pasien preeklamsi dengan atau tanpa sindroma HELLP komplit maupun parsial sehingga dapat menjadi sumber informasi dalam menyusun pedoman praktis di masa yang akan datang. Selain itu, dengan mengetahui faktor-faktor ini, diharapkan pedoman penatalaksanaan kasus sindroma HELLP dapat dikembangkan agar dapat memperbaiki prognosis bagi ibu dan bayi ke depannya.

\section{Metode}

Jenis penelitian ini berupa penelitian deskriptif retrospektif yang menggunakan data sekunder berupa rekam medis pasien preeklamsi di Rumah Sakit Umum Pusat Hasan Sadikin pada periode 1 januari 201131 desember 2016. Pengamatan ini dilakukan selama 1 bulan, yakni dari April-Mei 2017. Kemudian data diolah melalui proses pemeriksaan data, pemberian kode, dan penyusunan data. Selanjutnya, data dianalisis melalui program Microsoft Excel, dengan analisis deskriptif yang dilakukan pada setiap variabel.

Prosedur penelitian ini adalah sebagai berikut:

\section{a. Penyesuaian sampel}

Sampel penelitian dipastikan telah memenuhi kriteria inklusi dan tidak masuk ke dalam kriteria eksklusi. Kriteria inklusi merupakan subjek pasien di Rumah Sakit Umum Pusat Hasan Sadikin pada periode 1 Januari 201131 Desember 2016. Subjek kemudian dimasukkan ke dalam dua kelompok, yaitu kelompok preeklamsi tanpa sindroma HELLP dan kelompok preeklamsi dengan sindroma HELLP. Kemudian sampel dimasukkan ke dalam 2 kelompok, yaitu kelompok preeklamsi 
tanpa sindroma HELLP komplit maupun parsial, kelompok preeklamsi dengan sindroma HELLP komplit maupun parsial.

\section{b. Pemeriksaan kelengkapan data}

Sampel diperiksa kelengkapan datanya yang terdapat pada rekam medis dengan data yang diperlukan untuk penelitian.

\section{c. Simple Random Sampling}

Sampel diambil dengan menggunakan metode Simple Random Sampling pada kelompok preeklamsi tanpa sindroma HELLP. Yaitu sampel diambil dari pasien di RSUP Dr. Hasan Sadikin pada periode 1 Januari 2011-31 Desember 2016, tanpa dilakukan pemilihan khusus.

\section{d. Total Sampling}

Pada kelompok preeklamsi dengan sindroma HELLP komplit maupun parsial dilakukan pengambilan sampel dengan metode Total Sampling.

\section{Hasil}

Faktor risiko pada kelompok preeklamsi dengan sindroma HELLP komplit maupun parsial dan kelompok preeklamsi tanpa sindroma HELLP ini berdasarkan usia ibu, paritas, tekanan darah sistolik dan diastolik, dan riwayat hipertensi pada kehamilan sebelumnya.

Parameter laboratorium yang diperhitungkan yakni dengan melihat kadar hemoglobin, hematokrit, apus darah tepi, kadar LDH (dehidrogenase laktat), kadar bilirubin total, kadar AST (transaminase aspartate), dan kadar ALT (enzim transaminase alanina) pada kelompok preeklamsi dengan sindroma HELLP komplit maupun parsial dan kelompok preeklamsi tanpa sindroma HELLP.

Sindroma HELLP ditandai dengan hemolisis, peningkatan enzim hati, dan trombositopenia. Untuk mendiagnosis pasien dengan kearah sindroma HELLP perlu analisis keadaan subjek berkaitan dengan pembagian keadaan subjek, yakni : yang ditemukan subjek dengan hemolisis dan platelet rendah, hemolisis dan peningkatan enzim hati, platelet rendah dan peningkatan enzim hati, hemolisis, peningkatan enzim hati dan platelet rendah.

Komplikasi yang dapat terjadi pada Ibu dengan preeklamsi disertai sindroma HELLP maupun preeklamsi tanpa sindroma HELLP meliputi eklamsi, abrupsio plasenta, edema paru, stroke, koagulopati, sepsis, hingga kematian.

Janin yang dikandung oleh Ibu dengan preeklamsi disertai sindroma HELLP maupun preeklamsi tanpa sindroma HELLP dapat mengalami kemungkinan berat badan lahir rendah, lahir dengan skor APGAR rendah, IUFD (intrauterine fetal death), PJT (pertumbuhan janin terhambat), membutuhkan perawatan NICU, hingga kematian perinatal.

Pada tabel 1 parameter laboratorium yang diperhitungkan yakni dengan melihat kadar Hemoglobin, hematokrit, apus darah tepi, kadar LDH (dehidrogenase laktat), kadar bilirubin total, kadar AST (transaminase aspartate), dan kadar ALT (enzim transaminase alanina) pada kelompok preeklamsi dengan sindroma HELLP komplit maupun parsial dan kelompok preeklamsi tanpa sindroma HELLP.

Pada tabel 2 menjelaskan sindroma HELLP ditandai dengan hemolisis, peningkatan enzim hati, dan trombositopenia. Untuk mendiagnosis pasien dengan kearah sindroma HELLP perlu analisis keadaan subjek berkaitan dengan pembagian keadaan subjek, yakni : yang ditemukan subjek dengan hemolisis dan platelet rendah, hemolisis dan peningkatan enzim hati, platelet rendah dan peningkatan enzim hati, hemolisis, peningkatan enzim hati dan platelet rendah.

Pada tabel 3 komplikasi yang dapat terjadi pada Ibu dengan preeklamsi disertai sindroma HELLP maupun preeklamsi tanpa sindroma HELLP meliputi eklamsi, abrupsio plasenta, edema paru, stroke, koagulopati, 
Tabel 1 Gambaran Faktor Risiko pada Kelompok Preeklamsi Dengan Sindroma HELLP | Komplit maupun Parsial dan Kelompok Preeklmasi tanpa Sindroma HELLP

\begin{tabular}{lcccc}
\hline & \multicolumn{2}{c}{$\begin{array}{c}\text { Preeklamsi dengan } \\
\text { sindroma HELL }\end{array}$} & \multicolumn{2}{c}{$\begin{array}{c}\text { Preeklamsi tanpa } \\
\text { sindroma HELLP }\end{array}$} \\
\cline { 2 - 5 } & $\mathbf{n}=\mathbf{2 0 9}$ & $\mathbf{\%}$ & $\mathbf{n = 2 0 9}$ & $\mathbf{\%}$ \\
\hline Usia Ibu & & & & \\
$\quad<35$ tahun & 189 & 90,43 & 173 & 82,78 \\
$\geq 35$ tahun & 20 & 9,57 & 36 & 17,22 \\
Paritas & & & & \\
Primi & 133 & 63,63 & 127 & 60,77 \\
$\quad$ Multi & 76 & 36,36 & 82 & 39,23 \\
TDS & & & & \\
$\quad<160$ & 68 & 32,54 & 86 & 41,15 \\
$\geq 160$ & 141 & 67,46 & 123 & 58,85 \\
TDD & & & & \\
$\quad<100$ & 72 & 34,45 & 84 & 40,19 \\
$\geq 100$ & 137 & 65,55 & 125 & 59,81 \\
Riwayat HT pada kehamilan & & & & \\
sebelumnya & & & & \\
$\quad$ Ya & & & & \\
Tidak & 61 & 29,19 & 73 & 65,07 \\
\hline
\end{tabular}

Tabel 2 Gambaran Hasil Pemeriksaan Parameter Laboratorium Subjek Penelitian pada Kelompok Preeklamsi dengan Sindroma HELLP Komplit maupun Parsial dan Kelompok Preeklamsi tanpa Sindroma HELLP

\begin{tabular}{lcccc}
\hline & \multicolumn{2}{c}{$\begin{array}{c}\text { Preeklamsi dengan } \\
\text { sindroma HELLP }\end{array}$} & \multicolumn{2}{c}{$\begin{array}{c}\text { Preeklamsi tanpa } \\
\text { sindroma }\end{array}$} \\
\cline { 2 - 5 } & $\mathbf{n}=\mathbf{2 0 9}$ & $\mathbf{\%}$ & $\mathbf{n = 2 0 9}$ & $\mathbf{\%}$ \\
\hline Hb & & & & \\
Normal & 71 & 33,97 & 88 & 42,11 \\
Menurun & 138 & 66,03 & 121 & 57,89 \\
Het & & & & \\
Normal & 68 & 32,54 & 89 & 42,58 \\
Menurun & 141 & 67,46 & 120 & 57,42 \\
Apus darah tepi & & & & \\
Normal & 87 & 41,63 & 186 & 89,00 \\
Abnormal & 122 & 58,37 & 23 & 11,00 \\
Kadar LDH & & & & \\
$\quad$ Normal & 43 & 20,57 & 91 & 43,54 \\
Meningkat & 166 & 79,43 & 118 & 56,46
\end{tabular}


Lanjutan Tabel 2 Gambaran Hasil Pemeriksaan Parameter Laboratorium Subjek Penelitian pada Kelompok Preeklamsi dengan Sindroma HELLP Komplit maupun Parsial dan Kelompok Preeklamsi tanpa Sindroma HELLP

\begin{tabular}{clccc}
\hline & \multicolumn{2}{c}{$\begin{array}{c}\text { Preeklamsi dengan } \\
\text { sindroma HELLP }\end{array}$} & \multicolumn{2}{c}{$\begin{array}{c}\text { Preeklamsi tanpa } \\
\text { sindroma HELLP }\end{array}$} \\
\cline { 2 - 5 } & \multicolumn{2}{c}{$\mathbf{n = 2 0 9}$} & $\mathbf{\%}$ & \multicolumn{2}{c|}{$\mathbf{n = 9}$} & $\mathbf{\%}$ \\
\hline Bilirubin Total & & & & \\
Normal & 36 & 17,22 & 26 & 12,44 \\
Meningkat & 173 & 82,78 & 83 & 87,56 \\
Kadar AST & & & & \\
Normal & 31 & 14,83 & 191 & 91,39 \\
Meningkat & 178 & 85,17 & 18 & 8,61 \\
Kadar ALT & & & & \\
Normal & 26 & 12,44 & 195 & 93,30 \\
Meningkat & 183 & 87,56 & 14 & 66,70 \\
\hline
\end{tabular}

Tabel 3 Gambaran Diagnosis Subjek pada Kelompok Preeklamsi dengan Sindroma HELLP

\begin{tabular}{lcc}
\hline & \multicolumn{2}{c}{$\begin{array}{c}\text { Preeklamsi dengan } \\
\text { sindroma HELP }\end{array}$} \\
\cline { 2 - 3 } & $\mathbf{n = 2 0 9}$ & $\mathbf{\%}$ \\
\hline Hemolisis \& platelet rendah & 8 & 3,83 \\
Hemolisis \& peningkatan enzim hati & 93 & 44,50 \\
Platelet rendah \& peningkatan enzim hati & 53 & 25,36 \\
Hemolisis, peningkatan enzim hati \& platelet rendah & 55 & 26,32 \\
\hline
\end{tabular}

Tabel 4 Angka Kejadian Komplikasi Ibu pada Kasus Preeklamsi dengan dan tanpa Sindroma HELLP

\begin{tabular}{lcccc}
\hline & \multicolumn{2}{c}{$\begin{array}{c}\text { Preeklamsi dengan } \\
\text { sindroma HELLP }\end{array}$} & \multicolumn{2}{c}{$\begin{array}{c}\text { Preeklamsi tanpa } \\
\text { sindroma HELL }\end{array}$} \\
\cline { 2 - 5 } & $\mathbf{n}=\mathbf{2 0 9}$ & $\mathbf{\%}$ & $\mathbf{n = 2 0 9}$ & $\mathbf{\%}$ \\
\hline Eklamsi & 63 & 30,14 & 15 & 7,18 \\
Abrupsio plasenta & 25 & 11,96 & 4 & 1,91 \\
Gagal ginjal akut & 29 & 13,88 & 7 & 3,35 \\
Edema paru & 5 & 2,39 & 2 & 0,96 \\
Stroke & 1 & 0,48 & 0 & 0,00 \\
Koagulopati & 17 & 8,13 & 4 & 1,91 \\
Sepsis & 17 & 8,13 & 6 & 2,87 \\
Kematian & 4 & 1,91 & 3 & 1,44 \\
\hline
\end{tabular}


Tabel 5 Angka Kejadian Komplikasi Janin Pada Kasus Preeklamsi dengan dan tanpa Sindroma HELLP

\begin{tabular}{lcccc}
\hline & \multicolumn{2}{c}{$\begin{array}{c}\text { Prekklamsi dengan } \\
\text { sindroma HELLP }\end{array}$} & \multicolumn{2}{c}{$\begin{array}{c}\text { Preeklamsi tanpa } \\
\text { sindroma }\end{array}$} \\
\cline { 2 - 5 } & $\mathbf{n = 2 0 9}$ & $\mathbf{\%}$ & $\mathbf{n = 2 0 9}$ & $\mathbf{\%}$ \\
Berat badan lahir rendah & 170 & 81,34 & 122 & 58,37 \\
Skor APGAR $<7$ pada 1 & & & & \\
menit setelah kelahiran & 131 & 62,68 & 127 & 60,77 \\
IUFD & 31 & 14,83 & 4 & 191 \\
PJT & 56 & 26,79 & 41 & 19,62 \\
Dirawat di NICU & 130 & 62,20 & 53 & 25,36 \\
Mortalitas perinatal & 1 & 0,48 & 15 & 7,18 \\
\hline
\end{tabular}

sepsis, hingga kematian.
Pada tabel 4 Janin yang dikandung oleh Ibu dengan preeklamsi disertai sindroma HELLP maupun preeklamsi tanpa sindroma HELLP dapat mengalami kemungkinan berat badan lahir rendah, lahir dengan skor APGAR rendah, intrauterine fetal death (IUFD), dan pertumbuhan janin terhambat (PJT) membutuhkan perawatan NICU, hingga kematian perinatal.

\section{Pembahasan}

Tabel 1 menunjukkan gambaran beberapa faktor risiko yang berperan dalam terjadinya sindroma HELLP, antara lain usia maternal, paritas, tekanan darah sistolik maupun diastolik, serta riwayat hipertensi pada kehamilan sebelumnya. Tidak terdapat perbedaan yang jauh pada persentase usia maternal dan paritas yang ditemukan pada kelompok preeklampsi tanpa sindroma HELLP dan kelompok dengan sindroma HELLP.

Sebagian besar subjek datang dengan hipertensi stadium II. Hal tersebut dapat disebabkan oleh lokasi penelitian di Rumah Sakit Umum Pusat Hasan Sadikin yang merupakan pelayanan kesehatan tersier, sehingga hanya sedikit pasien yang dirujuk dengan hipertensi derajat ringan. Jumlah pasien dengan hipertensi stadium II, baik sistolik maupun diastolik, lebih banyak ditemukan pada kelompok preeklampsi dengan sindroma HELLP dibandingkan dengan kelompok tanpa sindroma HELLP.

Parameter hematologi dan biokimia pada kelompok preeklampsia dengan sindroma HELLP secara garis besar sangat berbeda dengan kelompok tanpa sindroma HELLP, akan tetapi pada jumlah subjek dengan abnormalitas pada pemeriksaan hemoglobin, hematokrit dan LDH, pada kedua kelompok tidak menunjukkan perbedaan yang banyak.

Pada kelompok preeklampsi dengan sindroma HELLP, komposisi antara subjek dengan sindroma HELLP parsial dan komplit, masing-masing, $73,68 \%$ dan $26,32 \%$. Sedangkan pada subjek dengan sindroma HELLP parsial, 5,19\% mengalami hemolisis dan jumlah platelet rendah, 60,39\% mengalami hemolisis dan peningkatan enzim hati, dan $34,42 \%$ mengalami jumlah platelet rendah dan peningkatan enzim hati.

Komplikasi-komplikasi maternal yang ditunjukkan pada penelitian ini, antara lain adalah eklamsi, abrupsio plasenta, gagal ginjal akut, edema paru, stroke, koagulopati, sepsis dan kematian maternal. Eklamsi banyak ditemukan pada kelompok preeklamsi dengan sindroma HELLP (30,14\%) dibandingkan dengan kelompok tanpa sindroma HELLP (7,18\%). Perbedaan yang cukup banyak terdapat pada abrupsio 
plasenta, yaitu $11,96 \%$ pada kelompok preeklamsi dengan sindroma HELLP dan hanya $1,91 \%$ pada kelompok tanpa sindroma HELLP.

Begitu juga dengan komplikasi gagal ginjal akut, yaitu 13,88\% dibandingkan dengan 3,35\%. Komplikasi-komplikasi yang terjadi pada subjek penelitian ini terdistribusi secara merata pada masa antepartum dan postpartum.

Berat badan lahir rendah banyak ditemukan di kelompok preeklamsi dengan sindroma HELLP $(81,34 \%)$ dibandingkan dengan kelompok tanpa sindroma HELLP $(58,37 \%)$. Perbedaan persentase yang cukup besar juga ditemukan pada komplikasi berupa perawatan bayi di NICU, yaitu $62,20 \%$ pada kelompok preeklamsi dengan sindroma HELLP dan 25,36\% pada kelompok tanpa sindroma HELLP. Sedangkan, komplikasikomplikasi janin lainnya, seperti skor Apgar $<7$ pada 1 menit setelah kelahiran, IUFD, PJT, dan mortalitas perinatal cenderung tidak jauh berbeda antara kelompok preeklamsi tanpa sindroma HELLP maupun pada kelompok dengan sindroma HELLP. Simpulan dari hasil penelitian dan pembahasan, dapat disimpulkan bahwa gambaran faktor risiko pada kedua kelompok tidak terdapat banyak perbedaan. Sedangkan pada parameter hematologi dan biokimia, lebih banyak abnormalitas yang ditemukan pada kelompok preeklamsi dengan sindroma HELLP dibandingkan dengan kelompok tanpa sindroma HELLP dan lebih sering pada subjek dengan sindroma HELLP parsial dibandingkan dengan sindroma HELLP komplit. Begitu pula dengan komplikasikomplikasi yang terjadi baik pada maternal maupun janin, lebih sering pada kelompok preeklamsi dengan sindroma HELLP, oleh karena itu, sindroma HELLP harus didiagnosis sedini mungkin pada ibu hamil maupun post partum dengan preeklamsi.

\section{Daftar Pustaka}

1. Fitzpatrick KE, Hinshaw K, Kurinczuk JJ, Knight M. Risk Factor, Management, and Outcome of Hemolysis, Elevated Liver Enzymes, and Low Platelets Syndrome and Elevated Liver Enzymes, Low Platelet Syndrome. Obstet Gynecol. 2014. 123(3):618-27.

2. Rakshit A, Lahiri S, Biswas SC, Dey R, Roy BR, Saha MM. A study to detect HELLP syndrome and partial HELLP syndrome among preeclamtic mothers and their impact on fetomaternal outcome. Al Ameen J Med Sci 2014;7(1):20-25.

3. Ara S, Singh BB, Birla N, Jyothi D. Incidence of Hellp Syndrome in Preeclampsia and Eclampsia \& Maternal and Perinatal Outcome Including Morbidity and Mortality. Indian J Res. 4 (7),2015; 65-7.

4. Atashkhoei S, Lame MM. Outcome of Patients Admitted to Obstetric Intensive Care Unit With Severe Preeclampsia, Eclampsia or HELLP Syndrome. Int J Women's Health. 2015, 155-157.

5. Cunningham FG, Leveno KJ, Bloom SL, Spong CY, Dashe JS, Hoffman BL, dkk. Williams Obstetrics 24th edition. 2014.

6. Markham KB, Funai EF. PregnancyRelated Hypertension. In: Creasy R. ed. Creasy and Resnik's Maternal-Fetal Med Princ Pract. 8th ed. Philadelphia, PA: Elsevier Saunders; 2017: chapter 48.

7. Sibai BM. Preeclampsia and Hypertensive Disorder. In: Complicated Pregnancy. 2017.

8. Martin JN, Brewer JM, Wallace $\mathrm{K}$, Sunesara I, Canizaro A, Blake PG, dkk.HELLP syndrome and composite major maternal morbidity: importance of Mississippi classification system. J Matern Fetal Neonatal Med. 2013 26(12): 1201-6.

9. Abildgaard U, Heimdal K. Pathogenesis of the syndrome of hemolysis, elevated 
liver enzymes, and low platelet count (HELLP): a review. Vol 166,issue 2,2013; pages 117-123.

10. Oliveira N, Poon LC, Nicolaides KH, Baschat AA. First trimester prediction of HELLP syndrome. Prenatal Diagnosis .2016; 36(1):29-33.

11. Stepan H, Hund M, Gencay M, Denk B, Dinkel C, Kaminski WE, dkk. A comparison of the diagnostic utility of the sFlt-1/PIGF ratio versus PIGF alone for the detection of preeclampsia/HELLP syndrome. Hypertension in Pregnancy. 2016; 35(3) : 295-305.

12. Haram K, Mortensen JH, Nagy B. Genetic Aspects of Preeclampsia and the HELLP Syndrome. Journal of Pregnancy. Vol 2014:13.

13. Pritchard NL, Keane JL. Wound haematoma: The first sign in a case of late postpartum HELLP syndrome. Case Report in Women's Health. 2015;8:1-3.

14. Weiner E, Schreiber L, Grinstein E, Feldstein O, Rymer-Haskel N, Bar J, dkk. The placental component and obstetric outcome in severe preeclampsia with and without HELLP syndrome. Placenta. 2016;47:99-104.

15. Dusse LM, Alpoim PN, Silva JT, Rios DR, Brandao AH, Carlos A.Revisiting HELLP syndrome. Europe PMC. 2015 Oct, 451(Pt B):117-120.

16. Martin JN. Milestones in the quest for best management of patients with HELLP syndrome (microangiopathic hemolytic anemia, hepatic dysfunction, thrombocytopenia). Int J Gynecol Obstet, 2013;121(3):202-207.

17. Vafaemanesh J, Nazari A, Hosseinzadeh F. Plasmapheresis: Lifesaving treatment in severe cases of HELLP syndrome. Caspain Journal of Internal Medicine. 2014;5(4) : 243-7.

18. Gracia PV, Suarez JR, Ramos E, Reyes O, Collantes J, Quintero A, dkk. Incidence of eclampsia with HELLP syndrome and associated mortality in Latin America. International Journal of Gynecology and Obstetric. 2015;129(3): 219-22.

19. Mao M, Chen C. Corticosteroid Therapy for Management of Hemolysis, Elevated Liver Enzymes, and Low Platelet Count (HELLP) Syndrome: A Meta-Analysis. Med Sci Monit. 2015; 21:3777-83.

20. Triggianese P, Perricone C, Perricone $\mathrm{R}$, Carolis CD. HELLP syndrome: a complication or a new autoimmune syndrome?.Reumatologia $\quad 2014 ; 52(6)$ : 377-83.

21. Aydin S, Ersan F, Ark C, Aydin CA. Partial HELLP syndrome: Maternal, perinatal, subsequent pregnancy and long-term maternal outcomes. The J Obstet Gynaecol Res.2014; 40(4) : 93240.

22. Miranda ML, Macher HC, Hernandez RM, Vaz AV, Luna RM, Villar J, dkk. Role of Circulating Cell-free DNA Levels in Patients With Severe Preeclampsia and HELLP Syndrome. Am J Hypertens. 2013; 26(12): 1377-80.

23. Tandon A, Chaudhari P, Gupta V, Ramola M. Feto-maternal outcome in patients with HELLP and partial HELLP syndrome: a prospective 10 year study in Shri Guru Ram Rai Institute of Medical and Health Sciences, Uttarakhand, India. Int J Reprod Contracep Obstet Gynecol. 2016; 5(9) : 3066-71.

24. Cornette J, Herzog E, Buijs EA, Duvekot JJ, Rizopoulos D, Hop WC, dkk. Microcirculation in women with severe pre-eclampsia and HELLP syndrome: a case-control study. BJOG. 2014; 121(3):363-70.

25. Katz L, Amorim M, Souza JP, Haddad SM, Cecatti JG, COHELLP Study Group. COHELLP: collaborative randomized controlled trial on corticosteroids in HELLP syndrome. Reproductive Health. 2013 May; 10:28.

26. Wallace K, Martin JN, Tam KT, 
Wallukat G, Dechend R, Lamarca B, Owens MY. Seeking the mechanism(s) of action for corticosteroids in HELLP syndrome: SMASH study. Am J Obstet Gynecol. 2013; 208(5)380. 